Ks. Dariusz Zalewski ${ }^{1}$

\title{
Rola i zadania prezbiterów we wspólnocie kościelnej w świetle pism Tertuliana
}

\section{Wprowadzenie}

Pisma Tertuliana są nieocenionym źródłem wiedzy do studium nad tworzeniem się struktur organizacji kościelnej. Ich autor wprawdzie nie napisał żadnego traktatu o Kościele, jednak w swoich okazjonalnych wypowiedziach o jego strukturze, urzędach i posługach wprowadza do użycia terminy, które z czasem wejdą do tradycji.

Jednym z takich terminów, wprowadzonych przez Afrykańczyka do chrześcijańskiej literatury łacińskiej i określających hierarchię kościelną, jest słowo clerus. Słowo to jest użyte przez Tertuliana w przeciwstawieniu do innego terminu - laici, który oznacza odrębną grupę w Kościele, różną od hierarchii kościelnej. W skład clerus wchodzą wyłącznie mężczyźni i są to zasadniczo episcopus, presbyter i diaconus ${ }^{3}$.

Innym terminem, przejętym przez Tertuliana z rzymskiej administracji państwowej i użytym przy opisie hierarchicznej struktury Kościoła, jest słowo $o r d o^{4}$. Podobnie jak w nazewnictwie prawniczym ordo odnosiło się do poszczególnych klas społeczeństwa rzymskiego (np. ordo senatorius, ordo

1 Ks. dr Dariusz Zalewski, pracownik Wyższego Seminarium Duchownego w Ełku; e-mail: darekz@tiscali.it; ORCID: 0000-0003-2051-1679.

2 Tertullianus, De virginibus velandis 9, 2, CCL 2, s. 1219.

3 Tertullianus, De baptismo 17, CCL 1, s. 291. Według A. Vilela (La condition collégiale des prêtres au IIIe siècle, Théologie Historique 14, Paris 1971, s. 232) w skład kleru wchodzili prawdopodobnie także lektorzy. Por. A. Cattaneo, I ministeri nella Chiesa antica. Testi patristici dei primi tre secoli, Milano 1997, s. 474.

4 Zob. P. van Beneden, Ordo. Über den Ursprung einer kirchlichen Terminologie, VigChr 23 (1969) s. 161-176. 
equester czy ordo decurionum), tak samo w Kościele można było wyróżnić różne ordines ecclesiastici. W skład ordines wchodzą przede wszystkim episcopus, dalej presbyteri, diaconi, prawdopodobnie lectores i viduae ${ }^{5}$. Oprócz ordines Kościół tworzą zwykli wierni nazywani przez Afrykańczyka plebs ${ }^{6}$.

Z powyższego wstępu jasno wynika, że wspólnota w Kartaginie za czasów Tertuliana podzielona była na dwie zasadnicze grupy. Do pierwszej należeli ci wierni, którzy obdarzeni byli różnego rodzaju urzędami, funkcjami i zajmowali specjalne miejsca, pozostali wierni natomiast, niepiastujący szczególnych stanowisk, tworzyli grupę drugą.

Najważniejszym członkiem pierwszej grupy wiernych był biskup. Sprawował on funkcję przewodnią we wspólnocie kartagińskiej i to jemu nasz autor poświęca najwięcej uwagi ${ }^{7}$. W swojej posłudze biskup wspomagany był przez grono prezbiterów, którym pragniemy poświęcić niniejsze rozważanie. Jego celem jest wyodrębnienie roli i zadań, jakie prezbiterom przypisywał Tertulian w swoich dziełach.

Struktura prezbiterów była obecna w Kościele już od samych początków jego istnienia. Wzmianki o tym znajdujemy chociażby w Dziejach Apostolskich czy listach św. Pawła. Na początku pojęcie presbyteroi było zamiennie używane z pojęciem episkopoi. Oba terminy odnosiły się do tej samej grupy starszych istniejącej w lokalnych wspólnotach chrześcijańskich ${ }^{8}$. Prawdopodobnie samo określenie presbyteroi zostało zaczerpnięte z synagogi, gdzie istniało kolegium ,starszych”. Określenie to miałoby funkcjonować we wspólnotach chrześcijańskich powstałych z judaizmu'. Ze względu na pełnione funkcje prezbiterzy byliby nazywani episkopoi przez chrześcijan wywodzących się ze środowisk pogańskich, którym tradycja żydowska była obca $^{10}$. Ścisłe rozróżnienie tych terminów nastąpiło w trakcie III wieku ${ }^{11}$.

5 Zob. Tertullianus, Ad uxorem 1, 7, 4, CCL 1, s. 381; Cattaneo, I ministeri nella Chiesa antica, s. 474.

6 Tertullianus, De exhortatione castitatis 7, 3, CCL 2, s. 1025: „Differentiam inter ordinem et plebem constituit ecclesiae auctoritas et honor per ordinis consessum sanctificatus a Deo".

7 Jeśli chodzi o urząd biskupa we wspólnocie kartagińskiej za czasów Tertuliana, zob. D. Zalewski, Pozycja biskupa we wspólnocie kościelnej na podstawie pism Tertuliana, w: Veni Sancte Spiritus. Księga pamiątkowa poświęcona Księdzu Biskupowi Jerzemu Mazurowi, red. W. Guzewicz - S. Strękowski, Ełk 2013, s. 503-519.

8 Zob. W. Bielak, Kilka uwag na temat początków urzędu biskupiego, VoxP 55 (2010) s. 69.

9 Odnosi się to szczególnie do Kościoła jerozolimskiego. Zob. W. Gajewski, Charyzmat, urzą, hierarchia, Kraków 2010, s. 130-142.

10 Zob. H. Pietras, Od prezbiteratu do kapłaństwa: ewolucja pojęć i urzędu, „Studia Bobolanum" 3 (2002) s. 5.

11 Bielak, Kilka uwag na temat początków urzędu biskupiego, s. 69. 
Podczas gdy piszący w drugiej połowie II wieku Ireneusz z Lyonu wydaje się jeszcze używać zamiennie pojęć episcopi i presbyteroi ${ }^{12}$, u Tertuliana, który swą działalność piśmienniczą zaczyna nieco później, rozróżnienie między tymi terminami jest już wyraźne.

W pismach Afrykańczyka termin presbyter występuje osiemnaście razy $^{13}$. Odnosi się on do drugiej grypy hierarchii kościelnej, usytuowanej zaraz po biskupie a poprzedzającej diakonów. Widać to wyraźnie, kiedy autor podaje listę osób, które mają prawo udzielać sakramentu chrztu:

Prawo udzielania chrztu posiada ze swej istoty najwyższy kapłan (summus sacerdos): którym jest biskup (episcopus). Następnie prezbiterzy i diakoni (presbyteri et diaconi), jednakże nie bez upoważnienia biskupa z racji godności Kościoła. Gdy się to przestrzega utrzymuje się pokój. Prawo to również przysługuje i laikom, ponieważ co otrzymuje się równym prawem, równym też można przekazać; oczywiście prawo to przysługuje laikom wówczas, jeśli już nie są wezwani biskupi, prezbiterzy czy diakoni (episcopi aut presbyteri aut diaconi $)^{14}$.

Słowo presbyter posiada więc u Tertuliana znaczenie techniczne, chociaż czasami jest użyte przez niego w swoim pierwotnym etymologicznym znaczeniu jako senex, senior. W ostatnim jednak przypadku Kartagińczyk używa je tylko przy fragmentach cytowanych z Biblii ${ }^{15}$.

Jak to zostało już ukazane wcześniej, prezbiterzy wchodzili w skład ordo ecclesiasticus. Aby jednak tam się dostać, musieli wykazać się nienagannym prowadzeniem oraz stałością w wierze: „Przewodniczą starsi i już wypróbowani (praesident probati quique seniores), którzy do urzędu (honorem) tego dochodzą nie za pieniądze, ale przez świadectwo (testimonio) czynów: za pieniądze bowiem nie dostanie żadnej rzeczy boskiej”"16.

Pomimo tego, iż w powyższym tekście pojawia się termin seniores, który niektórzy uczeni utożsamiają z seniores laici, specjalną grupą osób świeckich istniejącą w Kościele Afrykańskim ${ }^{17}$, termin „starsi” odnosi

12 Cattaneo, I ministeri nella Chiesa antica, s. 324.

13 G. Claesson, Index Tertullianeus, t. 2, Paris 1975, s. 1225.

14 Tertullianus, De baptismo 17, CCL 1, s. 291, tł. E. Stanula, Tertulian, O chrzcie, w: Tertulian, Wybór pism, opr. W. Myszor - E. Stanula, PSP 5, Warszawa 1970, s. 149-150.

15 H. Janssen, Kultur und Sprache. Zur Geschichte der alten Kirche im Spiegel der Sprachentwicklung von Tertullian bis Cyprian, Nijmegen 1938, s. 77.

16 Tertullianus, Apologeticum 39, 5, CCL 1, s. 150, tł. J. Sajdak, Quintus Septimius Florens Tertulian, Apologetyk, Poznań 1947, s. 157.

17 Zob. W.H.C. Frend, The seniores laici and the Origins of the Church in North Africa, JTS 12 (1961) s. 280-284. Por. P.G. Caron, Les ,, seniores laici“ de l'Église afri- 
się tu raczej do prezbiterów, na czele których stoi biskup ${ }^{18}$. Za taką interpretacją przemawia użycie czasownika praesident, który u Tertuliana związany jest z członkami kleru ${ }^{19}$. Zastosowanie terminu seniores mogłoby również być podyktowane nakazem tajemnicy (disciplina arcani), by nie dać do zrozumienia niewtajemniczonemu czytelnikowi, że chodzi o Eucharystię ${ }^{20}$.

Wspomniana grupa starszych obdarzona jest honor, termin ten w prawie rzymskim często jest stosowany do osób posiadających władzęę . Urząd ten otrzymali oni nie dzięki pieniądzom, lecz przez świadectwo (testimonio), jakie wydała o nich wspólnota ${ }^{22}$. Kandydat na urząd kościelny musiał więc być wypróbowany i godny zaufania (adlectio explorata ${ }^{23}$. Według Tertuliana wymogi te odróżniały Kościół od wspólnot heretyckich, gdzie wszystko dokonywało się w sposób chaotyczny ${ }^{24}$. W dziele De idolatria, pochodzącym już z czasu zafascyno-

caine, RIDA 6 (1951) s. 19; T. Kołosowski, Seniores laici w starożytnych wspólnotach kościelnych w Afryce Rzymskiej, „Seminare” 27 (2010) s. 216-217. Jednakże instytucja seniores laici w Kościele afrykańskim przeżywa swój rozkwit dopiero w IV i V wieku. Por. P. Monceaux, Histoire littéraire de l'Afrique chrétienne, t. 3, Paris 1905, s. 8; A.G. Hamman, Życie codzienne w Afryce pótnocnej w czasach św. Augustyna, tł. M. Stafiej-Wróblewska - E. Sieradzińska, Warszawa 1989, s. 297.

18 Według F. Oehler (Q.S.F. Tertulliani quae supersunt omnia, t. 1, Lipsiae 1853, s. 257-258, k) tytuł seniores swego czasu miał znaczenie generalne i odnosił się tak do biskupów, jak i do prezbiterów.

19 Zob. Tertullianus, De corona militis 3, 3, CCL 2, s. 1043: „Eucharistiae sacramentum [...] nec de aliorum manu quam praesidentium sumimus”. R. Uglione, , Corpus sumus" (Tert. Apol. 39), w: R. Uglione, Tertulliano. Teologo e scrittore, Brescia 2002, 40, n. 28.

20 C.B. Daly, Liturgical Worship in Tertullian's Africa, „The Irish Ecclesiastical Record" 94 (1960) s. 136-146. K. Adam (Kirchrnbegriff Tertullians. Eine dogmengeschichtliche Studie, Paderborn 1907, s. 60) sugeruje natomiast, że Afrykańczyk użył terminu seniores, ponieważ był bardziej zrozumiały dla pogan z Rzymu.

${ }_{21}$ T. Mommsen, Le droit publique romain, th. P.F. Girard, Paris 1892, s. 113.

22 Zdaniem V. Saxer (L'eucharistie chez Tertullien, „Parole et pain au service de renouveau" 46 (1971) s. 312) w analizowanym fragmencie termin testimonio można interpretować na dwa sposoby: w sensie aktywnym, jako świadectwo dawane przez starszych Chrystusowi, lub w sensie pasywnym, jako świadectwo wspólnoty o starszych. Według francuskiego uczonego druga możliwość wydaje się bardziej prawdopodobna.

23 Tertullianus, De praescriptione haereticorum 43, 5, CCL 1, s. 223.

24 Tertullianus, De praescriptione haereticorum 41, 6-8, CCL 1, s. 221-222: „Ordinationes eorum temerariae, leues, inconstantes. Nunc neophytos conlocant, nunc saeculo obstrictos, nunc apostatas nostros ut gloria eos obligent quia ueritate non possunt. Nusquam facilius proficitur quam in castris rebellium ubi ipsum esse illic promereri est. 
wania się Afrykańczyka błędami montanizmu, żali się on jednak, że do godności kościelnych dopuszcza się osoby niegodne:

Twórców bałwanów zalicza się do porządku kościelnego (ordinem ecclesiasticum). Co za zbrodnia! Raz jeden Żydzi wyciągnęli ręce do Chrystusa, ci codziennie godzą w Jego Ciało. O ręce zasługujące na odcięcie! Niech wreszcie zobaczą, czy nie znajdą się w podobnej sytuacji do tych, o których powiedziano: „Jeśli ręka twoja gorszy cię, odetnij ją”. Jakież ręce trzeba raczej odciąć, jak nie te, w których Ciało Pańskie doznaje zgorszenia? ${ }^{25}$.

Jeśli chodzi o szafowanie sakramentów, prezbiterzy we wszystkim uzależnieni są od biskupa. Kartagińczyk dokładnie to akcentuje w cytowanym powyżej fragmencie De baptismo, kiedy wymienia osoby mające prawo udzielania chrztu. Prezbiterzy pojawiają się zaraz po biskupie, a przed diakonami. Mogą oni udzielać chrztu, ,jednakże nie bez upoważnienia biskupa z racji godności Kościoła" ${ }^{26}$. Jak pisze dalej autor, podczas nieobecności kleru prawo to przysługuje również zwykłym wiernym, ,ponieważ co otrzymuje się równym prawem, równym też można przekazać" 27.

O aktywnym uczestnictwie prezbiterów podczas udzielania sakramentu chrztu świętego mówi Tertulian również w jednym z ostatnich swoich pism, De pudicitia:

Takim będzie człowiek-ciało i dusza, który odrodzony po chrzcie i wejściu kapłanów (sacerdotum) na nowo odzyskuje chropowatości i skazy ciała, i wyrzuca się go za miasto, na miejsce nieczyste; oddany zostaje on mianowicie szatanowi na zagładę ciała, i po upadku więcej nie jest odbudowywany w Kościele ${ }^{28}$.

Itaque alius hodie episcopus, cras alius; hodie diaconus qui cras lector; hodie presbyter qui cras laicus. Nam et laicis sacerdotalia munera iniungunt".

25 Tertullianus, De idolatria 7, 3, CCL 2, s. 1106, tł. K. Obrycki, Tertulian, O batwochwalstwie, w: Tertulian, Wybór pism III, opr. T. Kołosowski - I. Salamonowicz-Górska, PSP 65, Warszawa 2007, s. 132.

26 Tertullianus, De baptismo 17, CCL 1, s. 291, tł. E. Stanula, Tertulian, O chrzcie, s. 149.

27 Tertullianus, De baptismo 17, CCL 1, s. 291, tł. E. Stanula, Tertulian, O chrzcie, s. 149.

28 Tertullianus, De pudicitia 20, 12, CCL 2, s. 1325, tł. K. Obrycki, Tertulian, O wstydliwości, w: Tertulian, Wybór pism III, opr. T. Kołosowski - I. SalamonowiczGórska, PSP 65, Warszawa 2007, s. 244. 
Wydaje się, że w powyższym tekście kartagińczyk przypisuje prezbiterom funkcje kapłańskie ${ }^{29}$. Sugerowałoby to użycie liczby mnogiej przez naszego autora. Oczywiście biskup przewodziłby tej grupie. Ponadto termin sacerdos jest stosowany przez Tertuliana w sposób szczególny w odniesieniu do chrztu i Eucharystii ${ }^{30}$. Potwierdzenie tego znajdujemy w dziele De exhortatione castitatis, w którym autor pragnie odwieść ludzi świeckich od powtórnego małżeństwa po śmierci współmałżonka. Prawo to obowiązywało kler, jednak Tertulian chce rozszerzyć je na wszystkich wierzących:

Czyż i my jako laicy nie jesteśmy kapłanami. Napisane jest: „I uczynił także z nas królestwo kapłanów mających służyć Bogu i Ojcu swojemu”. Władza Kościoła ustanowiła różnicę pomiędzy stanem kapłańskim a ludem, a Bóg odbiera cześć przez uświęconą godność stanu kapłańskiego (ordinis consessum). Kiedy nie ma zgodności kapłaństwa kościelnego (ecclesiastici ordinis consessus), sobie samemu i składasz ofiarę (offers) i chrzcisz (tinguis) i jesteś kapłanem (sacerdos es tibi solus); gdzie mianowicie są trzej, jest Kościół, chociażby byli to ludzie świeccy ${ }^{31}$.

W cytowanym tekście pojawia się wyrażenie ecclesiastici ordinis consessus, które odsyła nas do zgromadzeń chrześcijańskich, gdzie tylko niektórzy członkowie hierarchii kościelnej mogli zajmować miejsca siedzące, podczas gdy pozostali stali razem z ludem. Tę elitarną grupę wewnątrz ordo stanowili biskup i prezbiterzy ${ }^{32}$. Według Tertuliana to oni są zwyczajnymi szafarzami chrztu świętego i Eucharystii. Gdy zajdzie jednak potrzeba, także świeccy, jak się wydaje, mogą pełnić funkcje kapłańskie ${ }^{33}$.

Pomimo tego, iż Afrykańczyk pisze o możliwości sprawowania funkcji kapłańskich przez świeckich, to możliwe jest to tylko w nadzwyczajnych sytuacjach, kiedy jest nieobecny biskup lub delegowana przez niego osoba z kleru. Co ciekawe, argumentacja Tertuliana ma raczej podłoże dyscyplinarne niż teologiczne. Według naszego autora uprzywilejowanie

29 Kapłaństwo zwykłego kapłana, uczestniczącego w kapłaństwie biskupa, jest przez Tertuliana oznaczone zarówno terminem sacerdos, jak i presbyter. Por. H. Wójtowicz, Terminologia kaptańska u Tertuliana, VoxP 13-15 (1993-1995) s. 84.

30 P. Mattei, ,, Habere ius sacerdotis”. Sacerdoce et laïcat au témoignage de Tertullien De exhortatione castitatis et De monogamia, RevSR 59 (1985) s. 220.

31 Tertullianus, De exhortatione castitatis 7, 3, CCL 2, s. 1025, tł. K. Obrycki, Tertulian, Zachęta do czystości, w: Tertulian, Wybór pism II, opr. K. Myszor - K. Obrycki - E. Stanula, Warszawa 1983, s. 172-173.

32 G. Bardy, Le sacerdoce chrétien d'apres Tertulien, VS 58 (1939) s. 111, n. 8.

33 Użyte w tekście czasowniki offerre i tinguere mają znaczenie techniczne. Por. P. Mattei, ,Habere ius sacerdotis”, s. 210-211. 
kleru bierze swoje źródło w decyzji władzy kościelnej ${ }^{34} \mathrm{i}$ służy zachowaniu porządku oraz pokoju w Kościele ${ }^{35}$.

Afrykańczyk wymienia również prezbiterów w gronie osób, których zadaniem jest nadzorowanie zawieranych małżeństw:

Skoro więc zgodnie z nauką Apostoła chcesz „wyjść za mąż w Panu” (jeśli mimo wszystko zależy ci na tym), jaka jesteś, domagając się małżeństwa i to od tych, którym nie wolno się powtórnie żenić: od biskupa monogamicznego, od prezbiterów i również diakonów związanych tym sakramentem czy też wdów, których sposób życia odrzucasz ${ }^{36}$.

Wydaje się więc, że w Kościele Afrykańskim była instytucja składająca się z przedstawicieli poszczególnych ordines ecclesiastici, która czuwała nad praworządnością zawieranych małżeństw. Na jej czele stał z pewnością biskup ${ }^{37}$.

W De anima, piśmie zdradzającym już wpływ montanizmu na Tertuliana, spotykamy prezbitera pochylającego się nad ciałem zmarłej kobiety:

Wiem, iż pewna kobieta, należąca do Kościoła już od urodzenia, zmarła w pokoju, będąc w kwiecie wieku i piękna, po jednym i krótko trwającym małżeństwie; podczas gdy trwały uroczystości pogrzebowe i ciało było składane do grobu w czasie modlitwy prezbitera $[\ldots]^{38}$.

Powyższy fragment jest niestety jedynym tekstem, w którym Tertulian wspomina o obecności kleru podczas pogrzebu. Nie jest do końca pewne, czy była to prerogatywa wyłącznie prezbiterów czy też termin presbyter został użyty tu przez autora w znaczeniu ogólnym. W ostatnim przypadku należałoby się raczej spodziewać terminu sacerdos $^{39}$.

34 Tertullianus, De exhortatione castitatis 7, 3, CCL 2, s. 1025: „, Differentiam inter ordinem et plebem constituit ecclesiae auctoritas [...]".

35 Tertullianus, De baptismo 17, CCL 1, s. 291: ,[...] propter ecclesiae honorem quo salvo salva pax est".

36 Tertullianus, De monogamia 11, 1, CCL 2, s. 1244, tł. E. Stanula, Tertulian, O jednożeństwie, w: Tertulian, Wybór pism III, opr. T. Kołosowski - I. Salamonowicz-Górska, PSP 65, Warszawa 2007, s. 73.

37 Por. Ch. Munier, Matrimonio e verginità nella Chiesa antica, ed. G. Ramella, Torino 1990, s. 243, n. 2.

38 Tertullianus, De anima 51, 6, CCL 2, s. 857: „Scio feminam quandam uernaculam ecclesiae, forma et aetate integra functam, post unicum et breue matrimonium cum in pace dormisset et morante adhuc sepultura interim oratione presbyteri componeretur [...]" (tł. własne).

39 D.I. Rankin, Tertullian and the Church, Cambridge 2007, s. 168. 
Prezbiterzy odgrywają również istotną rolę w czasie ponownego przyjmowania grzesznika do wspólnoty. Podczas publicznej pokuty penitenci padają na kolana przed nimi i pozostałymi członkami wspólnoty, prosząc o wstawiennictwo:

W worku i popiele leżeć, ciało mieć w brudzie i zaniedbaniu, ducha w smutku i żałobie pognębić, grzechy przez gorzkie wspomnienie odwołać, pożywienie i napój bez przypraw spożywać, oczywiście nie ze względu na brzuch, lecz tylko dla utrzymania życia; często zaś modlitwy swoje postami wzmacniać, jęczeć, płakać i wołać dzień i noc do Pana Twego, przed kapłanami (presbyteris) bić czołem o ziemię, a tych, którzy mili są Bogu, obejmować za kolana, wszystkich zaś braci prosić o wstawiennictwo w przebłaganiu za grzechy ${ }^{40}$.

Uniżenie się grzeszników przed prezbiterami w akcie pokutnym było więc rodzajem instytucji kościelnej i miało miejsce przed oficjalnym rozgrzeszeniem oraz ponownym włączeniem do wspólnoty wierzących ${ }^{41}$. Opis podobnego rytu penitencjarnego znajduje się w dziele De pudicitia, gdzie grzesznicy klęczą na środku kościoła przed prezbiterami i wdowami, szukając pomocy wstawienniczej ${ }^{42}$. W obydwu jednak przypadkach prezbiterzy spełniają co najwyżej rolę świadków dających swoje modlitewne wsparcie, prawdopodobnie bez jakiejkolwiek mocy lub prawa do rozgrzeszania ${ }^{43}$.

Podsumowując, należy stwierdzić, iż pozycja prezbiterów we wspólnocie w czasach Tertuliana była już ugruntowana. Stanowili oni drugi stopień hierarchii, zaraz po biskupie, a przed diakonami. Ich rola i zadania, jakie mogliśmy ustalić z analizy dzieł kartagińczyka, sprowadzały się do bycia pomocnikami biskupa. Na uwagę zasługuje fakt, że u Tertuliana spotykamy się z najstarszym świadectwem łączenia dotychczasowej funkcji prezbiterów ze słownictwem i funkcją kapłańską. Jako uczestniczący w kapłaństwie biskupa presbyteri mogli spełniać munera sacerdotalia, jednak zawsze za wiedzą i zgodą episcopa.

40 Tertullianus, De paenitentia 9, 4, CCL 1, s. 335, tł. E. Stanula, Tertulian, O pokucie, w: Tertulian, Wybór pism, opr. W. Myszor - E. Stanula, PSP 5, Warszawa 1970, s. 188-189.

41 J. Quasten, Patrologia, t. 1, Casale 1980, s. 541.

42 Tertullianus, De pudicitia 13, 7, CCL 2, s. 1304: „Et tu quidem paenitentiam moechi ad exorandam fraternitatem in ecclesiam inducens conciliciatum et concineratum cum dedecore et horrore compositum prosternis in medium ante uiduas, ante presbyteros, omnium lacrimas suadentem, omnium uestigia lambentem, omnium genua detinentem, inque eum hominis exitum quantis potes misericordiae inlecebris bonus pastor et benedictus papa contionaris et in parabola ouis capras tuas quaeris?".

43 Zob. Rankin, Tertullian and the Church, s. 168-169. 


\section{The Function and Mission of Presbyters in Tertullian's Works}

(summary)

Tertullian did not bequeath any treaty directly about Church and organization of it. Well, he certainly did not regard it as something required. The aggregate of his works quite precise shows how Church in North Africa functioned in II and III century. In his works term presbyter it seems to be ultimately stated. The term determines the second level of beadle, subordinate authority of supervisor of community - pontiff. For that reason, presbyters did not arouse our author, who frequently lists them in relation with the superior. They participated in actions appropriate for pontiff such as education or gave baptism to somebody. Moreover, they confirm Christian marriage and they achieve intercessory function while public expiation sinners. However, they probably do not possess power to absolve worshippers. Tertullian especially point out their disciplinary function, they had to provide peace in the community although they create with pontiff and deaconry the hierarchy in Church.

Keywords: Church; Tertullian; North Africa; presbyters

\section{Rola i zadania prezbiterów we wspólnocie kościelnej w świetle pism Tertuliana}

(streszczenie)

Tertulian nie pozostawił po sobie żadnego traktatu dotyczącego sensu stricto Kościoła i jego organizacji. Z pewnością nie widział takiej potrzeby. Całokształt jego twórczości daje jednak wystarczająco precyzyjny obraz organizacji kościelnej w Afryce Północnej na przełomie II i III wieku. Termin presbyter w dziełach kartagińczyka wydaje się już ostatecznie ustalony. Jest on użyty przez niego na określenie urzędu kościelnego drugiego stopnia, podporządkowanego we wszystkim władzy przełożonego wspólnoty. Z tego też powodu prezbiterzy nie wzbudzają większego zainteresowania naszego autora, który często wymienia ich tylko w relacji do zwierzchnika wspólnoty. Uczestniczą oni w czynnościach ministerialnych właściwych biskupowi, takich jak nauczanie czy udzielanie chrztu. Ponadto prezbiterzy uczestniczą w zatwierdzaniu chrześcijańskich małżeństw oraz spełniają rolę wstawienniczą podczas publicznej pokuty grzeszników. Prawdopodobnie nie posiadają oni jednak władzy odpuszczania grzechów. Pomimo tego, iż prezbiterzy wraz z biskupem i diakonami tworzą hierarchię w Kościele, to Tertulian zasadniczo podkreśla ich rolę dyscyplinarną mającą zapewnić pokój we wspólnocie.

Słowa kluczowe: Kościół; Tertulian; Afryka Północna; prezbiterzy 


\section{Bibliografia}

\section{Źródła}

Tertullianus, Ad uxorem, ed. E. Kroymann, CCL 1, Turnholti 1954, s. 371-394, tt. K. Obrycki, Tertulian, Do żony, w: Tertulian, Wybór pism II, PSP 29, Warszawa 1983, s. 147-164.

Tertullianus, Apologeticum, ed. E. Dekkers, CCL 1, Turnholti 1954, s. 77-171, t1. J. Sajdak, Tertulian, Apologetyk, POK 20, Poznań 1947.

Tertullianus, De anima, ed. J.H. Waszink, CCL 2, Turnholti 1954, s. 779-869.

Tertullianus, De baptismo, ed. J.G.P. Borleffs, CCL 1, Turnholti 1954, s. 275-295, tł. E. Stanula, Tertulian, O chrzcie, w: Tertulian, Wybór pism, PSP 5, Warszawa 1970, s. $133-154$.

Tertullianus, De corona militis, ed. A. Kroymann, CCL 2, Turnholti 1954, s. 1037-1065.

Tertullianus, De exhortatione castitatis, ed. E. Kroyman, CCL 2, Turnholti 1954, s. 10131035, th. K. Obrycki, Tertulian, Zachęta do czystości, w: Tertulian, Wybór pism II, PSP 29, Warszawa 1983, s. 165-181.

Tertullianus, De idolatria, ed. A. Reifferscheid - G. Wissowa, CCL 2, Turnholti 1954, s. 1099-1124, tł. K. Obrycki, Tertulian, O batwochwalstwie, w: Tertulian, Wybór pism III, PSP 65, Warszawa 2007, s. 127-151.

Tertullianus, De monogamia, ed. E. Dekkers, CCL 2, Turnholti 1954, s. 1227-1253, tł. E. Stanula, Tertulian, O jednożeństwie, w: Tertulian, Wybór pism III, PSP 65, Warszawa 2007, s. 59-82.

Tertullianus, De paenitentia, ed. J.G.P. Borleffs, CCL 1, Turnholti 1954, s. 319-340, tt. E. Stanula, Tertulian, O pokucie, w: Tertulian, Wybór pism, PSP 5, Warszawa 1970, s. $175-192$.

Tertullianus, De praescriptione haereticorum, ed. R.F. Refoulé, CCL 1, Turnholti 1954, s. 185-224, tł. E. Stanula, Tertulian, Preskrypcja przeciw heretykom, w: Tertulian, Wybór pism, PSP 5, Warszawa 1970, s. 40-78.

Tertullianus, De pudicitia, ed. E. Dekkers, CCL 2, Turnholti 1954, s. 1279-1330, tł. K. Obrycki, Tertulian, $O$ wstydliwości, w: Tertulian, Wybór pism III, PSP 65, Warszawa 2007, s. 199-248.

Tertullianus, De virginibus velandis, ed. E. Dekkers, CCL 2, Turnholti 1954, s. 1207-1226, t1. K. Obrycki, Tertulian, O noszeniu zasłony przez dziewice, w: Tertulian, Wybór pism III, PSP 65, Warszawa 2007, s. 85-103.

\section{Opracowania}

Adam K., Kirchrnbegriff Tertullians. Eine dogmengeschichtliche Studie, Paderborn 1907.

Bardy G., Le sacerdoce chrétien d'apres Tertulien, VS 58 (1939) s. 109-124. 
Beneden van P., Ordo. Über den Ursprung einer kirchlichen Terminologie, VigChr 23 (1969) s. 161-176.

Bielak W., Kilka uwag na temat początków urzędu biskupiego, VoxP 55 (2010) s. 63-76.

Caron P.G., Les ,, seniores laici” de l'Église africaine, RIDA 6 (1951) s. 7-22.

Cattaneo A., I ministeri nella Chiesa antica. Testi patristici dei primi tre secoli, Milano 1997.

Claesson G., Index Tertullianeus, t. 2, Paris 1975.

Daly C.B., Liturgical Worship in Tertullian's Africa, „The Irish Ecclesiastical Record” 94 (1960) s. 136-146.

Frend W.H.C., The seniores laici and the Origins of the Church in North Africa, JTS 12 (1961) s. 280-284.

Gajewski W., Charyzmat, urząd, hierarchia, Kraków 2010.

Hamman A.G., Życie codzienne w Afryce północnej w czasach św. Augustyna, tł. M. Stafiej-Wróblewska - E. Sieradzińska, Warszawa 1989.

Janssen H., Kultur und Sprache. Zur Geschichte der alten Kirche im Spiegel der Sprachentwicklung von Tertullian bis Cyprian, Nijmegen 1938.

Kołosowski T., Seniores laici w starożytnych wspólnotach kościelnych w Afryce Rzymskiej, ,Seminare” 27 (2010) s. 215-222.

Mattei P., „Habere ius sacerdotis”. Sacerdoce et lä̈at au témoignage de Tertullien De exhortatione castitatis et De monogamia, RevSR 59 (1985) s. 200-221.

Mommsen T., Le droit publique romain, tł. P.F. Girard, Paris 1892.

Munier Ch., Matrimonio e verginità nella Chiesa antica, ed. G. Ramella, Torino 1990.

Monceaux P., Histoire littéraire de l'Afrique chrétienne, t. 3, Paris 1905.

Pietras H., Od prezbiteratu do kapłaństwa: ewolucja pojęć i urzędu, „Studia Bobolanum” 3 (2002) s. 5-17.

Quasten J., Patrologia, t. 1, Casale 1980.

Rankin D.I., Tertullian and the Church, Cambridge 2007.

Saxer V., L'eucharistie chez Tertullien, „Parole et pain au service de renouveau” 46 (1971) s. 309-325.

Uglione R., ,, Corpus sumus” (Tert. Apol. 39), w: R. Uglione, Tertulliano. Teologo e scrittore, Brescia 2002, s. 35-46.

Vilela A., La condition collégiale des prêtres au IIIe siècle, Théologie Historique 14, Paris 1971.

Wójtowicz H., Terminologia kapłańska u Tertuliana, VoxP 13-15 (1993-1995) s. 77-88.

Zalewski D., Pozycja biskupa we wspólnocie kościelnej na podstawie pism Tertuliana, w: Veni Sancte Spiritus. Księga pamiątkowa poświęcona Księdzu Biskupowi Jerzemu Mazurowi, red. W. Guzewicz - S. Strękowski, Ełk 2013, s. 503-519. 